\title{
Effect of Exhaust Gas on Natural Stone Tablets, a Laboratory Experiment
}

\author{
Orsolya Farkas ${ }^{1,2}$ Ákos Török ${ }^{1 *}$ \\ ' Department of Engineering Geology and Geotechnics, Faculty of Civil Engineering, \\ Budapest University of Technology and Economics, \\ H-1521 Budapest, P.O.B. 91, Hungary \\ ${ }^{2}$ KTI Institute for Transport Sciences Non-Profit Ltd., H-1518 Budapest, P.O.B. 107, Hungary \\ *Corresponding author, e-mail: torokakos@mail.bme.hu
}

Received: 18 June 2018, Accepted: 14 November 2018, Published online: 28 November 2018

\begin{abstract}
8 different natural stone types were exposed to exhaust gas under laboratory conditions to assess urban stone damage. $3 \mathrm{~cm}$ in diameter cylindrical test specimens were made from travertine, non-porous limestone, limestone, rhyolite tuff, sandstone, andesite, granite and marble. The samples were exposed for 1, 2, 4 and 8 hours to exhaust gas that was generated by compression ignition internal combustion engine. The exhaust emission was measured. The operating conditions of the engine were documented and several parameters (weight, density, ultrasonic pulse velocity, capillary water absorption, porosity) were measured before and after exhaust gas exposure. The tests indicate that despite the deposition of soot on the surface a significant material loss was recorded at rhyolite tuff $(2 \mathrm{~m} \%)$ and at andesite $(1 \mathrm{~m} \%)$. The penetration depth of soot was also different for different lithologies. A correlation was found between the ultrasonic pulse velocity and density of tested stones.
\end{abstract}

\section{Keywords}

diesel engine, exhaust gas, natural stone, porosity, weight loss

\section{Introduction}

Natural stones are frequently used in constructions and applied outside and inside. One of the key problems of external use is the discoloration and damage of building facades. The colour changes can be attributed to air pollution, in the form of deposition of pollutants which lead to blackening of building stone [1-3]. The blackening process clearly related to particulate matter [4]. The blackening and formation of soiling layer have been described for various stone types including marble [5-6], limestone $[4,7,8]$, travertine [9] and even on volcanic rocks [1011]. The soiling is related to particle deposition and incorporation into the newly formed gypsum layers [12] and also causes other changes in physical properties such as strength that influences durability [3]. The colour change reflects air quality and thus millennium long changes can be also recorded [13]. In the past decades vehicles were the main causes of urban stone decay, however air pollution can cause damage in stone structures located in rural settings $[11,14]$. The colour change and sulfation process can be modelled under laboratory conditions where carbonate samples are exposed to exhaust gas (particulates) and SOx [15]. The changes can be recorded by testing newly formed mineral phases and also by measuring colour changes [2].

Our basic aim was to investigate the aesthetic effect of air pollution derived from road vehicle's engine on stones widely used for construction and decoration. The main question is how this induced pollution contribute to accelerated weathering and how the exhaust gas related particulate matters influence the colour of stone slabs. Similar chamber test was applied to evaluate the role of particulate matter coming from vehicular sources on stone sulfation [15]. This paper focuses on changes of physical properties rather than on mineralogical alterations of stone slabs having different composition.

\section{Materials}

The tests were carried out on 8 different stone types. These types of stones have been chosen because they are used widely and they have very different physical and chemical properties. The tested natural stones are widely used 
in buildings and structures as dimension and ornamental stones in Hungary [16-17]. Except for Carrara marble from Italy and Mauthausen granite from Austria, the tested 6 other stone types were obtained from Hungarian quarries. Cylindrical tests specimens with a diameter of 3 $\mathrm{cm}$ were used for the tests (Fig. 1).

Selected types of stones (and their localities of origin) are given here (from left to right on Fig. 1):

top row:

- porous limestone (Sóskút)

- rhyolite tuff (Sirok)

- sandstone (Romhány)

- travertine (Süttő)

bottom row:

- granite (Mauthausen)

- andesite (Gyöngyös)

- non-porous limestone (Tardos)

- marble (Carrara)

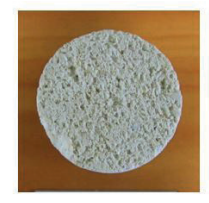

Porous limestone

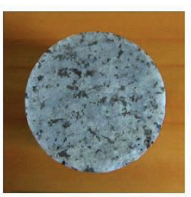

Granite

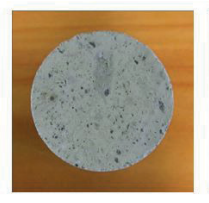

Rhyolite tuff

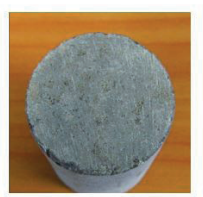

Andesite

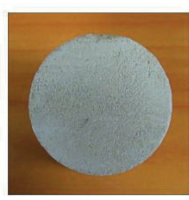

Sandstone

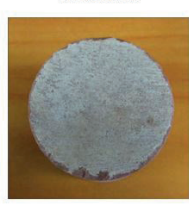

Non-porous limetone

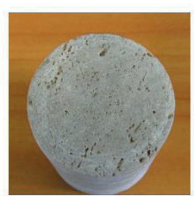

Travertine

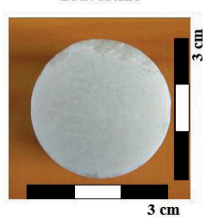

Marble ${ }^{3 \mathrm{~cm}}$
Fig. 1 Stone types (see explanation in the text)

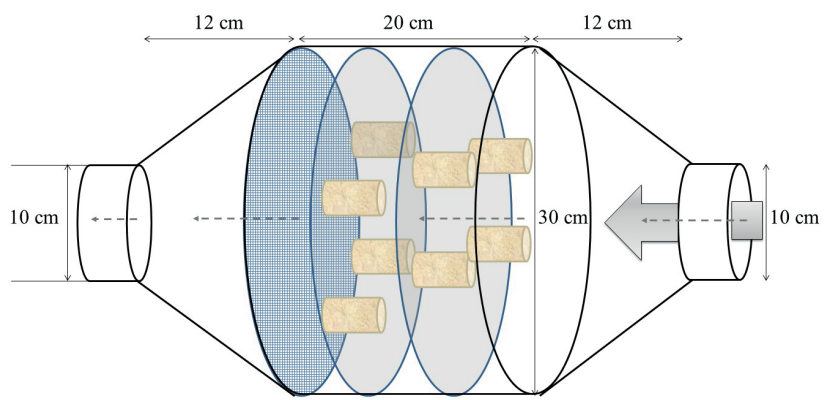

Fig. 2 Cylindrical samples in the exposure chamber
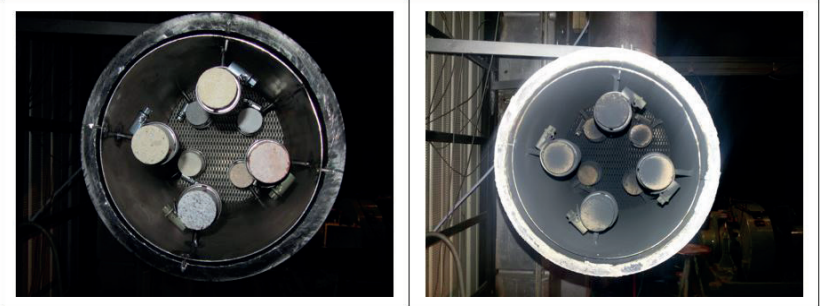

Fig. 3 Prior to and after exhaust gas exposure
Table 1 Measured emission data and temperature

\begin{tabular}{lcccc}
\hline & $1 \mathrm{~h}$ & $2 \mathrm{~h}$ & $4 \mathrm{~h}$ & $8 \mathrm{~h}$ \\
\hline $\mathrm{O}_{2}[\%]$ & 12.9 & 12.9 & 13.01 & 12.9 \\
$\mathrm{CO}_{2}[\%]$ & 5.919 & 6.023 & 6.101 & 6.107 \\
$\mathrm{CO}[\mathrm{ppm}]$ & 142.7 & 141.3 & 139.8 & 144.7 \\
$\mathrm{CH}[\mathrm{ppm}]$ & 59.9 & 57.8 & 61.4 & 62.3 \\
$\mathrm{NO}_{x}[\mathrm{ppm}]$ & 680.1 & 688.2 & 693.4 & 716.8 \\
$\mathrm{NO}[\mathrm{ppm}]$ & 537.2 & 540.5 & 542.0 & 553.4 \\
$\mathrm{k}$ value $\left[\mathrm{m}^{-1}\right]$ & 0.065 & 0.076 & 0.072 & 0.077 \\
Temperature $\left[{ }^{\circ} \mathrm{C}\right]$ & 245.0 & 244.5 & 247.3 & 246.9 \\
\hline
\end{tabular}

\section{Methods}

\subsection{Pollution of stones - exposure chamber}

A block of 8 different stone types was placed in a chamber, which was built in the exhaust gas system of a compression ignition internal combustion engine, so the exhaust gas of the engine was led through the chamber. In this case the exhaust stream could contact directly to the surface of the material specimens. The location of the samples in the exposure chamber is given on Fig. 2, while samples prior and after the test are shown on Fig. 3.

A compression ignition engine was used to generate exhaust gas to pollute directly the stones. The most important data of the engine are listed in Table 1. This engine was running on conventional diesel, which was purchased from a petrol station in Budapest.

The engine was operated for 1, 2, 4 and 8 hours at one operating point. Operating conditions (1300 r/min and $50 \%$ load) of the RÁBA D10 UTSLL 160, EuroII engine were controlled and the temperature inside the chamber, gas phase components and $\mathrm{k}$ absorption coefficient were continuously measured during the test. The engine operating point was chosen due to the higher $\mathrm{k}$ value [18-21]. The fuel used was gas oil complying with MSZ EN 590 from MOL fuel station. The fuel consumption was 3,91 $\mathrm{g} / \mathrm{s}$ and the mass flow of exhaust gas was approximately $475 \mathrm{~kg} / \mathrm{h}$.

\subsection{Laboratory tests}

Measurements regarding the mass of the stones before and after the pollution have been carried out with the help of the analytical balance (Kern AES Analytical Balance).

Ultrasonic pulse velocity values were measured by $5 \mathrm{~cm}$ in diameter Pundit transmitter and receiver ultrasonic velocity tester. The test procedure is described in details by EN 14579 .

The pore distribution was evaluated by a mercury porosimeter (Carlo Erba - GFZ Potsdam) at University of Goettingen, Germany. Capillary water absorption tests 
were made following the guidelines given by European Norm (EN 1925) on tests specimens of each lithotypes.

The penetration depth of soot was recorded based on the visual inspection of specimens that were broken into halves during indirect tensile strength test (Brasilian).

\section{Results and discussion}

\subsection{Physical properties}

The saturation of porous stones (porous limestone, rhyolite tuff, sandstone and travertine) was shorter it took 8.5 hours during capillary water absorption tests (Fig. 4), while the saturation of non-porous stones (granite, andesite, non-porous limestone, marble) took at least 16 hours (Fig. 5). The porous limestone absorbed the highest amount of water at the shortest period of time. The water absorption also caused colour changes. The most visible one was observed at rhyolite tuff (Fig. 4).

Water absorption was higher on porous limestone, rhyolite tuff and sandstone.

The lowest density of studied stones was measured at porous limestone, while the highest one was documented in granite (Fig. 6).

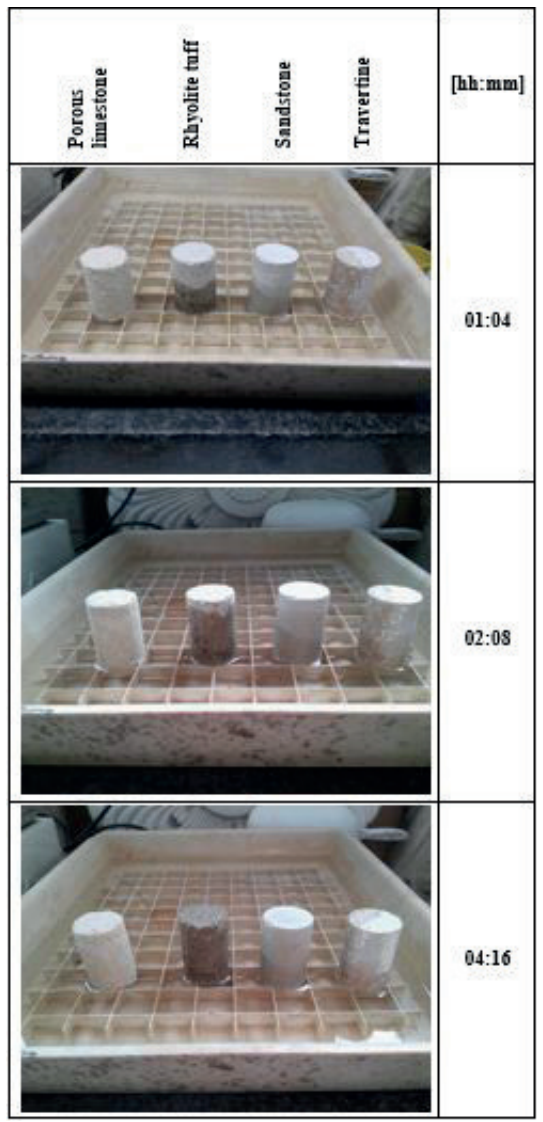

Fig. 4 Capillary water absorption of stones (porous limestone, rhyolite tuff, sandstone and travertine) as time progresses

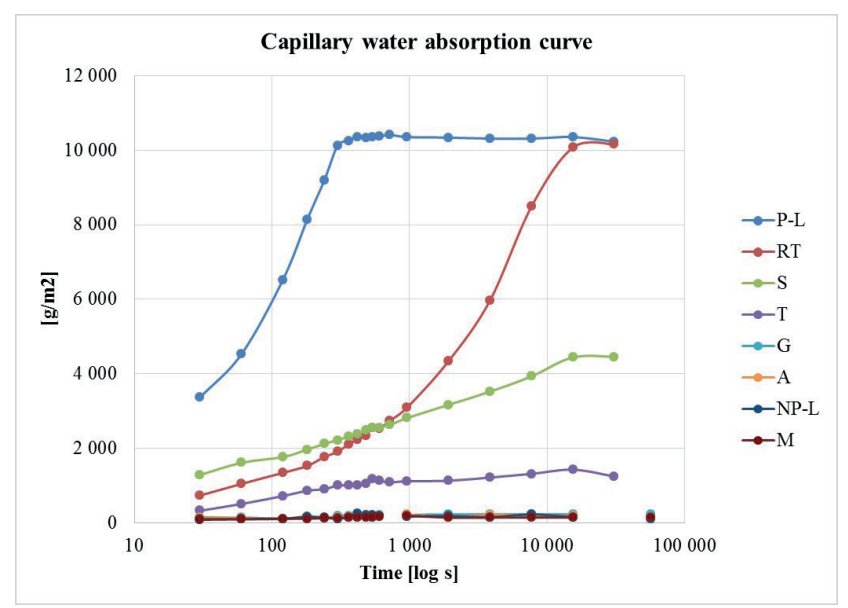

Fig. 5 Capillary water absorption curves (porous limestone - blue, rhyolite tuff - red, sandstone - green and travertine - purple)

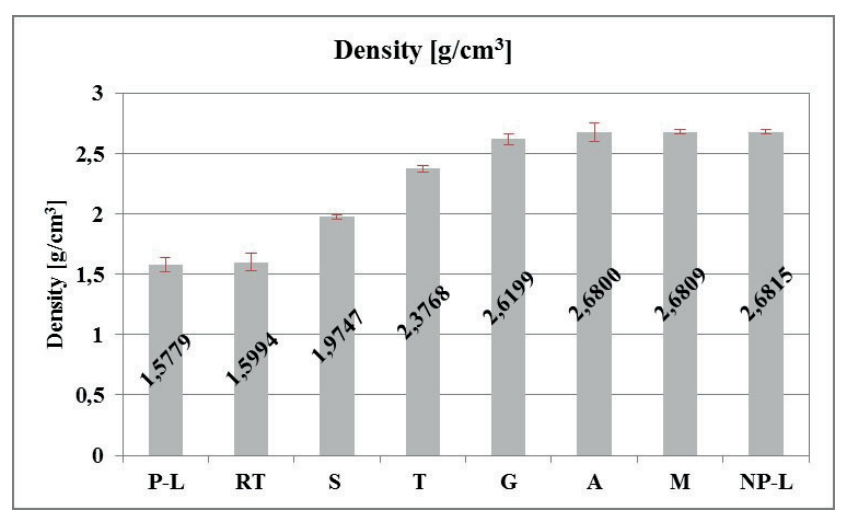

Fig. 6 Density of selected stones (P-L: porous limestone, RT: rhyolite tuff, S: sandstone, T: travertine, G: granite, A: andesite, M: marble, NPL: non-porous limestone)

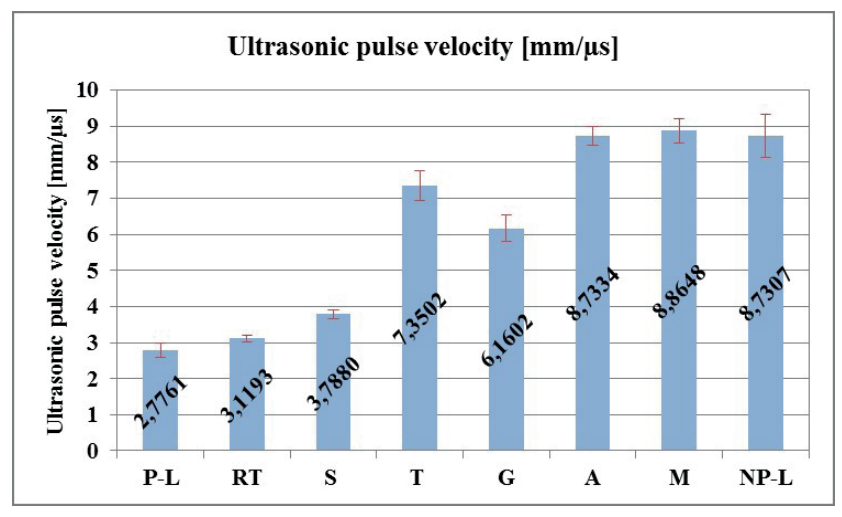

Fig. 7 Ultrasonic pulse velocity

The ultrasonic pulse velocity of marble was the highest, while has been plotted in the next figure (Fig. 7), while stones are in the same order than it was the case of Fig. 6.

Figure 8 shows density in function the ultrasonic pulse velocity. It can be see both the own measurement results and the results derived from the [22-23]. Tested highly porous, low density stones (porous limestone, rhyolite 
tuff and sandstone) are found in a distinct field that overlaps with the data obtained from literature. The measured higher density stones have higher UPV values than the ones mentioned in the previous works [23].

In order to be able to investigate the values of density and ultrasonic pulse velocity a regression analysis was made for three tested stone types: porous limestone, travertine and non-porous limestone (Table 2). These equations show that there is a good correlation between obtained values and that of the previous studies [22, 23, 24].

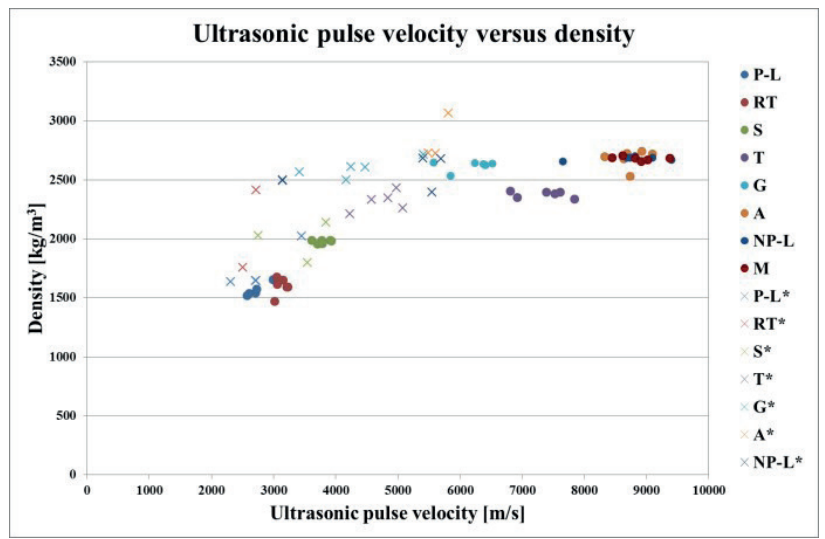

Fig. 8 Ultrasonic pulse velocity versus density (this study: • literature data: $x[22-23])$

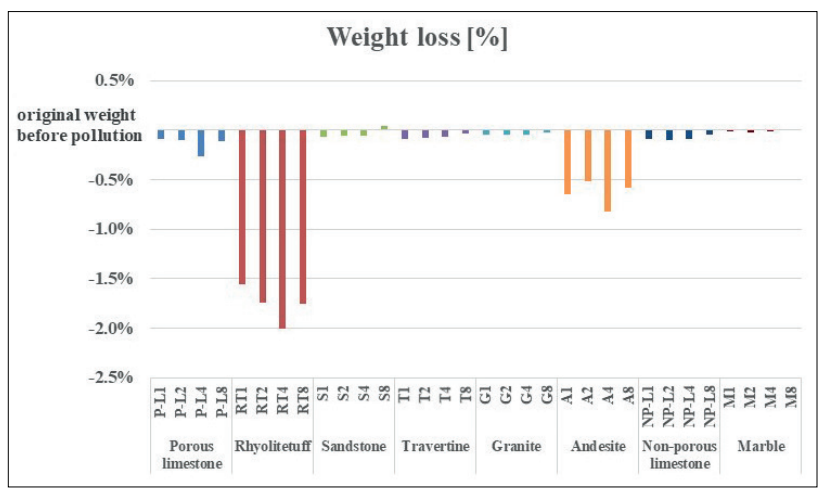

Fig. 9 Weight loss in percentage of the original stone weight before the 1, 2, 4 and 8 hours long pollution treatments

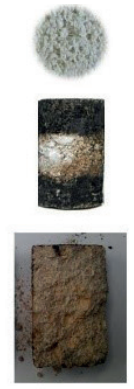

POROus LIMFSTONE
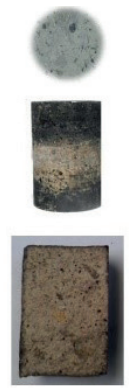

RHYOLITE

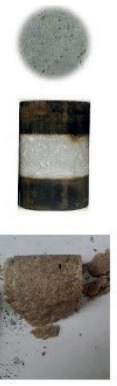

TRAVERTINE

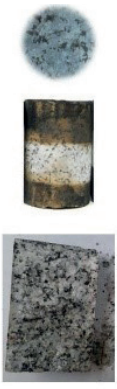

GRANIIE
Fig. 10 Penetration depth in 4 different textures after 4 hours (from left to right: porous limestone, rhyolite tuff, travertine, granite)
Table 2 Correlation between ultrasonic pulse velocity (V) and density (d) of different limestones (*: this study, **: [23] ***: [22])

\begin{tabular}{lcc}
\hline Stonetype & Regression equation & $\begin{array}{c}\text { Coeffitient of } \\
\text { determination }\left(\mathrm{R}^{2}\right)\end{array}$ \\
\hline Non-porous limestone $(*)$ & $\mathrm{d}=0.0297 \mathrm{~V}+2429.0$ & 0.8174 \\
Non-porous limestone $(* *)$ & $\mathrm{d}=0.0758 \mathrm{~V}+2258.9$ & 0.9871 \\
Travertine $(*)$ & $\mathrm{d}=0.0601 \mathrm{~V}+1936.2$ & 0.8052 \\
Travertine $(* *)$ & $\mathrm{d}=0.2608 \mathrm{~V}+1114.7$ & 0.9162 \\
Porous limestone $(*)$ & $\mathrm{d}=0.2767 \mathrm{~V}+809.87$ & 0.9467 \\
Porous limestone $(* *)$ & $\mathrm{d}=0.3713 \mathrm{~V}+698.1$ & 0.8552 \\
Limestone - cubes $(* * *)$ & $\mathrm{d}_{\mathrm{c}}=0.28 \mathrm{~V}_{\mathrm{c}}+935.56$ & 0.8193 \\
Limestone - prisms $(* * *)$ & $\mathrm{d}_{\mathrm{p}}=0.46 \mathrm{~V}_{\mathrm{p}}+538.49$ & 0.7214 \\
\hline
\end{tabular}

Table 3 Porosity values of pure and polluted porous limestone for $4 \mathrm{~h}$

\begin{tabular}{cccccc}
\hline & $\begin{array}{c}\text { Without } \\
\text { pollution }\end{array}$ & $\begin{array}{c}\text { D4_T } \\
\text { top }\end{array}$ & $\begin{array}{c}\text { D4_F } \\
\text { upper }\end{array}$ & $\begin{array}{c}\text { D4_K } \\
\text { middle }\end{array}$ & $\begin{array}{c}\text { D4_A } \\
\text { bottom }\end{array}$ \\
\hline Porosity [Vol. \%] & 38.38 & 30.96 & 34.16 & 34.12 & 31.98 \\
\hline
\end{tabular}

\subsection{Changes of parameters before and after the exposure}

In order to calculate the changes in weight of stones mass were measured prior to exposure trials and after each exposure period. Despite the fact that probes were discolored by the deposited soot on the stone surface, weight loss was measured at all the 8 stone types (Fig. 9).

It is probably linked to the high temperature of the exhaust gas that caused mineralogical changes. Interstitial water of layered silicates was removed and that could cause the mass loss of rhyolite tuff and andesite.

The penetration depth of soot was different for different lithologies. Pores of porous limestone, rhyolite tuff, travertine and granite were filled with particulate matter after 4 hours of exposure test (Fig. 10). Other stones with dense structure have been covered by particulate, but deep penetration was not observed by visual inspection.

Pore-size distribution of porous limestone has been investigated for fresh stone and for specimens that were subjected to exhaust gas (4 hours). Measurements were made at 4 different heights of the stone specimens: 1. top surface layer which is directly exposed to the flow of exhaust gas, 2. cylinder surface layer in the upper third part of the stone, 3. cylinder surface layer under the surface of fixing ring, 4. cylinder surface layer in the lower part of the specimens (Fig.11).

Greatest level of decrease in porosity was observed in the layers number 1 and 4, which are exposed surfaces of cylinder (Fig. 11, Table 3). 


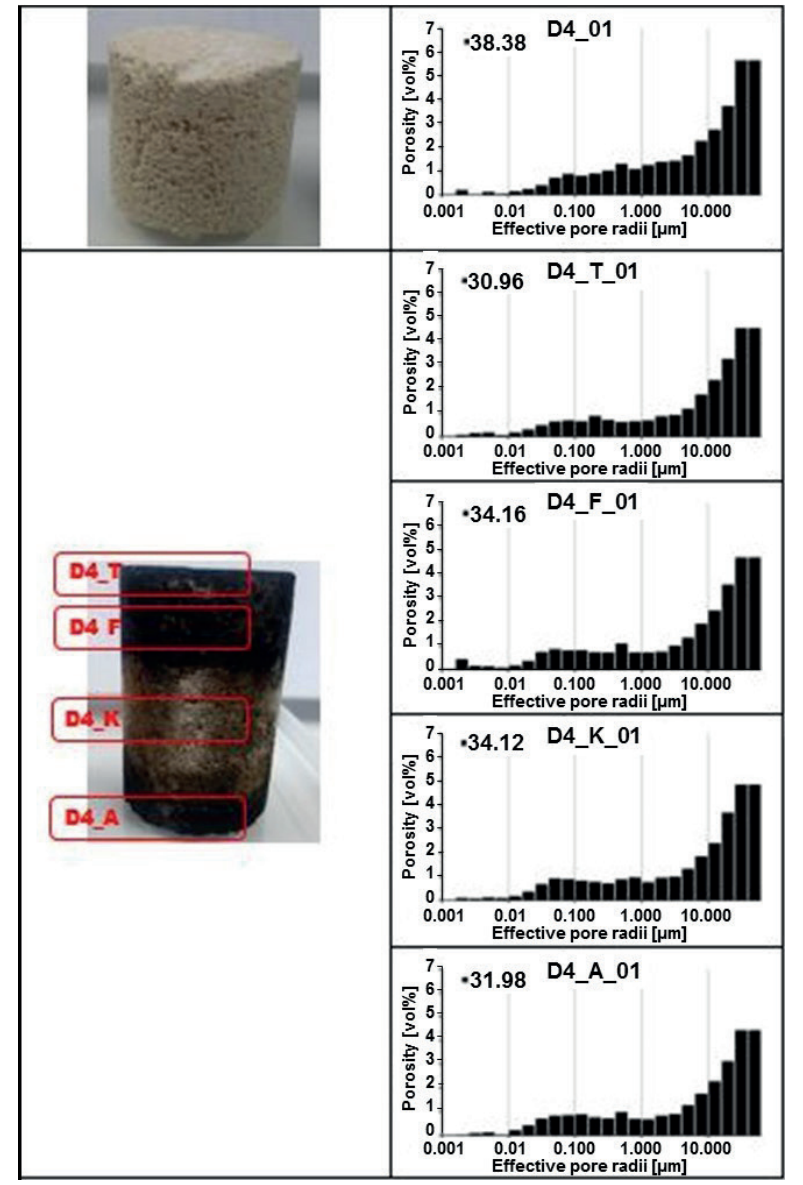

Fig. 11 Pore distribution in different layers of porous limestone before and after 4 hours long pollution

The visual inspection of colour changes suggests that the exhaust gas caused major discolouration as it was previously recorded [21], but this colour change could be different under different illuminations. It was pointed out in the previous studies of pure natural stones [25], but additional research is needed to describe the colour changes caused by exhaust gas under different illuminations.

\section{Conclusions}

The exposure to exhaust gas caused different weight loss of samples. The highest loss in weight was recorded at rhyolite tuff $(2 \mathrm{~m} \%)$, and the mass of andesite specimens also reduced by $1 \mathrm{~m} \%$, while the weight loss of all other lithologies were less than $0.1 \mathrm{~m} \%$. An increase in weight were found after 8 hours of exposure indicating the deposition of soot particles on the samples.

Our test has demonstrated the differences between 1, 2, 4 and 8 hours exposition, but this change may depend on not only time period, but also the temperature, surface roughness, porosity, in addition to the amount of soot derived from the exhaust gas.
There were clearly visible colour differences between the samples exposed for different time.

The weight loss may be related to the high temperature in the chamber and the mineralogical composition and probably mark changes in mineralogical composition and loss of interstitial water of layered silicate structures.

\section{Acknowledgement}

The financial support of National Research, Development and Innovation (NKFI) Fund (K 116532) is appreciated. We are grateful to György Szabados, György Horváth and János Jaksa for the construction of pollution chamber and measurement of the vehicle and exhaust gas parameters. The help of Prof. Siegfried Siegesmund, Christian Knell and Christopher Pötzl in porosimetry analyses are appreciated. The research reported in this paper was supported by the Higher Education Excellence Program of EMMI in the frame of the Water sciences \& Disaster Prevention research area of BME (BME FIKP-VÍZ).

\section{References}

[1] Bonazza, A., Sabbioni, C., Ghedini, N. "Quantitative data on carbon fractions in interpretation of black crusts and soiling on European built heritage", Atmospheric Environment, 39(14), pp. 2607-2618, 2005. https://doi.org/10.1016/j.atmosenv.2005.01.040

[2] Grossi, C. M., Brimblecombe, P. "Effect of long-term changes in air pollution and climate on the decay and blackening of European stone buildings", Geological Society Special Publication, 271(1), pp. 117-130, 2007.

https://doi.org/10.1144/GSL.SP.2007.271.01.13

[3] Urosevic, M., Yebra-Rodríguez, A., Sebastián-Pardo, E., Cardell, C. "Black soiling of an architectural limestone during two-year term exposure to urban air in the city of Granada (S Spain)", Science of the Total Environment, 414, pp. 564-575, 2012. https://doi.org/10.1016/j.scitotenv.2011.11.028

[4] Amoroso, G. G., Fassina, V. "Stone Decay and Conservation: Atmospheric Pollution, Cleaning, Consolidation, and Protection", Elsevier, Amsterdam, Netherlands, 1983.

[5] Moropoulou, A., Bisbikou, K., Torfs, K., Van Grieken, R., Zezza, F., Macri, F. "Origin und growth of weathering crusts on ancient marbles in industrial atmosphere", Atmospheric Environment, 32(6), pp. 967-982, 1998.

https://doi.org/10.1016/S1352-2310(97)00129-5

[6] Pozo-Antonio, J. S., Pereira, M. F. C., Rocha, C. S. A. "Microscopic characterisation of black crust on different substrates", Science of the Total Environment, 584-585, pp. 291-306, 2017. https://doi.org/10.1016/j.scitotenv.2016.12.080

[7] Fobe, B. O., Vleugels, G. J., Roekens, E. J., Van Grieken, R. E., Hermosin, B., Ortega-Calvo, J. J., del Junco, A. S., Saiz-Jimenez, C. "Organic and inorganic compounds in limestone weathering crusts from cathedrals in southern and western Europe", Environmental Science and Technology, 29(6), pp. 1691-1701, 1995. https://doi.org/10.1021/es00006a038 
[8] Maravelaki-Kalaitzaki, P., Biscontin, G. "Origin, characteristics and morphology of weathering crusts on Istria stone in Venice", Atmospheric Environment, 33(11), pp. 1699-1709, 1999. https://doi.org/10.1016/S1352-2310(98)00263-5

[9] Török, Á. "Black crusts on travertine: factors controlling development and stability", Environmental Geology, 56(3-4), pp. 583594, 2008.

https://doi.org/10.1007/s00254-008-1297-x

[10] Germinario, L., Siegesmund, S., Maritan, L., Simon, K., Mazzoli, C. "Trachyte weathering in the urban built environment related to air quality", Heritage Science 5(44), p. 17, 2017. https://doi.org/10.1186/s40494-017-0156-z

[11] Graue, B., Siegesmund, S., Oyhantcabal, P., Naumann, R., Licha, T., Simon, K. "The effect of air pollution on stone decay: the decay of the Drachenfels trachyte in industrial, urban, and rural environments - a case study of the Cologne, Altenberg and Xanten cathedrals", Environmental Earth Sciences 69(4), pp. 1095-1124, 2013. https://doi.org/10.1007/s12665-012-2161-6

[12] Sabbioni, C. "Contribution of atmospheric deposition to the formation of damage layers", Science of the Total Environment, 167(1-3), pp. 49-55, 1995. https://doi.org/10.1016/0048-9697(95)04568-L

[13] Brimblecombe, P., Grossi, C. M. "Millennium-long damage to building materials in London", Science of the Total Environment, 407(4), pp. 1354-1361, 2009.

https://doi.org/10.1016/j.scitotenv.2008.09.037

[14] Török, Á., Licha, T., Simon, K., Siegesmund, S. "Urban and rural limestone weathering; the contribution of dust to black crust formation", Environmental Earth Sciences, 63(4), pp. 675-693, 2011. https://doi.org/10.1007/s12665-010-0737-6

[15] Rodriguez-Navarro, C., Sebastian, E. "Role of particulate matter from vehicle exhaust on porous building stones (limestone) sulfation", Science of the Total Environment, 187(2), pp. 79-91, 1996. https://doi.org/10.1016/0048-9697(96)05124-8

[16] Török, Á. "Hungarian dimensional stones: an overview", Zeitschrift der Deutschen Gesellschaft für Geowissenschaften, 158(3), pp. 361-374, 2007.

https://doi.org/10.1127/1860-1804/2007/0158-0361

[17] Siegesmund, S., Török, Á. "Building Stones", In: Stone in Architecture, 4th ed., Springer, Berlin, Germany, pp. 11-95. 2011. https://doi.org/10.1007/978-3-642-14475-2_2

[18] Szabados, Gy., Bereczky, Á. "Comparison Tests of Diesel, Biodiesel and TBK-Biodiesel", Periodica Polytechnica Mechanical Engineering, 59(3), pp. 120-125, 2015. https://doi.org/10.3311/PPme.7989

[19] Szabados, Gy., Merétei, T. "Comparison tests of fossil diesel fuel and TBK-biofuel", Periodica Polytechnica Transportation Engineering, 43(4), pp. 218-224, 2015. https://doi.org/10.3311/PPtr.7963

[20] Ajtai, T., Pintér, M., Utry, N., Kiss-Albert, G., Gulyás, G., Pusztai, P., Puskás, R., Bereczky, Á., Szabados, Gy., Szabó, G., Kónya, Z., Bozóki, Z. "Characterisation of diesel particulate emission from engines using commercial diesel and biofuels", Atmospheric Environment, 134, pp. 109-120, 2016. https://doi.org/10.1016/j.atmosenv.2016.03.046
[21] Farkas, O., Szabados, Gy., Antal, Á., Török, Á. "Experimental Investigation of Discoloration Generated by a CI ICE's Exhaust Gas on Various Stone Types", Periodica Polytechnica Transportation Engineering, 46(3), pp. 158-163, 2018. https://doi.org/10.3311/PPtr.12120

[22] Concu, G., De Nicolo, B., Valdes, M. "Prediction of building limestone physical and mechanical properties by means of ultrasonic P-wave velocity", The Scientific World Journal, p. 8, 2014. https://doi.org/10.1155/2014/508073

[23] Bedzsula, M., Török, Á. "Ultrahang hullámok terjedése különböző kőzetekbe", (Ultrasonic pulse velocity in different lithologies) presented et Mérnökgeológia-Kőzetmechanika 2015, Budapest, Hungary, 2015. pp. 271-278, (in Hungarian) Avialable at http://www.mernokgeologia.bme.hu/ocs/index.php/konferencia/ MGEO2015/paper/viewFile/242/233 [Accessed: 28.11.2018]

[24] Pappalardo, G., Mineo, S., Monaco, C. "Geotechnical characterization of limestones employed for the reconstruction of a UNESCO world heritage Baroque monument in southeastern Sicily (Italy)", Engineering Geology, 212, pp. 86-97, 2016. https://doi.org/10.1016/j.enggeo.2016.08.004

[25] Antal, Á., Görög, P., Veres, Á. L., Balla, B., Török, Á. "Colour of stone slabs under different standard illuminations", Periodica Polytechnica Civil Engineering, 61(1), pp. 66-74, 2017. https://doi.org/10.3311/PPci.9038 